\title{
MARKETING STRATEGIES \& IMPROVED OPTIMIZATION OF COMPETENCE OF ENTREPRENEURSHIP: SURVEY OF SMALL AND MEDIUM BUSINESS IN INDONESIA CERAMIC ICONIC PRODUCTS
}

\author{
Dede R. Oktini \\ Doctoral Program Management, University of Pasundan Bandung; \\ Program Management Studies, Islamic University of Bandung, Bandung - Indonesia \\ dede.r.oktini@gmail.com
}

\begin{abstract}
This study was conducted to determine the effect of market strategy, marketing mix strategy and entrepreneurial competencies to competitive advantage of marketing and its implications on the performance of ceramic iconic product marketing in West Java. The total sample of 220 respondents, the owners of small and medium-scale ceramic enterprises in West Java. The sampling method used power analysis techniques. Data collected through observation, interviews and surveys using questionnaires instrument closed and open. The analytical method used is Structural Equation Model. The results found that the influence of the entire independent variables significantly influence the intervening variable, and the effect of intervening variables significantly influence the independent variable. The amount of direct influence on competitive advantage strategy marketing market by $3.8 \%$, the magnitude of the direct influence of marketing mix strategy on competitive advantage of marketing at $11.5 \%$, the magnitude of the direct influence of entrepreneurial competencies to competitive advantage of marketing by $15.6 \%$. The magnitude of the direct effect of the competitive advantage of marketing to marketing performance by $9.1 \%$. Sequentially important variable is the competence of entrepreneurship, marketing mix strategy, market strategy, marketing competitive advantage. Marketing competitive advantage is influenced by market strategy, marketing mix strategy and entrepreneurial competence by $65 \%$, while the remaining $35 \%$ are influenced by other factors (ceteris paribus). To 5 hypothesis proposed in this study were all found.
\end{abstract}

Keywords: market strategy, marketing mix strategies, entrepreneurial competence, the competitive advantage of marketing, performance marketing

\section{Introduction}

Indonesian Government Regulation No. 17 of 2013 explaining his support for business development that is innovative, creative and prioritized as the main program of regional development, the Government should improve the performance of the sector (Musthopa et al, 2017, p.58) and make a significant contribution (Rahmayanti, 2018, p.1). Sub sectors of the creative economy that is developed is craft, and one type is a ceramic produced by micro, small and medium enterprises / SMEs (Regulation of the Minister of Industry No. 135 / M-IND / PER / 10/2009). Government programs are intended to increase the GDP and improve people's lives (Triawan, Munaf, 2017) These objectives can be achieved through the optimization of marketing strategies and improve the competence of entrepreneurial businesses that will enhance the competitive advantage of marketing and the impact on marketing performance. The marketing strategy for the budget requires minimal effort and optimal creativity in order to appropriately and effectively.

West Java is a region where the growing centers of ceramics whose existence has long existed. Ceramic is a product of fashion and culture at the same time is an iconic areas in West Java, its existence is the main attraction because of its uniqueness. This product is very supportive in the enliven the West Java tourism that is growing. West Java ceramic development potential is still very large because it is supported by the availability of abundant raw materials, is able to absorb the labor force, large production 
capacity. Besides the importance of preserving and developing the ability to produce so that it becomes a skill / professionalism that can be applied to other types of ceramics, even nonclay, which in turn increases the role of this industry become an important sector.

Ceramics in West Java has long existence, but has not been able to produce good continuous innovation of products, pricing, distribution, promotion can be used as a marketing competitive advantage. Marketing performance based on the observation can be seen from the number of outlets is reduced, visitors to the outlets in each location centers deserted, factory activity was quiet, not many furnaces in operation, the number of workers employed seemed just a little, the traffic of raw materials lonely, do not seem to activities of transport of goods in bulk big. This was confirmed by the opinion of some business owners complained lonely visitors and lead to inadequate number of production. UPTD states ceramics export value realization has decreased, it is still far from the target, not compete with ceramics from Vietnam. On the other hand.

These weaknesses caused by several things including market strategy (segmenting, targeting, positioning). Based on observations and preliminary interviews on some businesses, not all of classifying (segmenting) and select segments clearly (targetting) and the lack of building a unique beneficial and can distinguish it from competitors and does not communicate (positioning), as a result of marketing strategy is less precise and less effective. The other weakness is caused due to weak marketing mix strategy. Coaching centers, especially to artisans in West Java more intensive ceramics but is still far from complete, trainees are still limited in number so that of all the artisans that still exist only a few developing products (innovative). Prasetyono (02/18/2018) says, ceramic marketing Plered controlled by marketers in Jakarta, Bandung and Bogor. Crafters more helpless determine their selling prices because of a lack of mastery of information technology. Marketers sell ceramics to overseas buyers through the internet at a price of 3-4 times more expensive than the purchase price to artisans. Another problem is indicated by the reduction in the number of outlets, but the kind of market extends to hotels and property. Ceramic western Java distributed through independent middlemen, outlet or retail store and the web (Marketers sell ceramics to overseas buyers through the internet at a price of 3-4 times more expensive than the purchase price to artisans. Another problem is indicated by the reduction in the number of outlets, but the kind of market extends to hotels and property. Ceramic western Java distributed through independent middlemen, outlet or retail store and the web (Marketers sell ceramics to overseas buyers through the internet at a price of 3-4 times more expensive than the purchase price to artisans. Another problem is indicated by the reduction in the number of outlets, but the kind of market extends to hotels and property. Ceramic western Java distributed through independent middlemen, outlet or retail store and the web (www.kramikplered.com). Currently there are promotional activities carried out by the craftsmen through outlets helped by a salesperson, assisted by the government, following the exhibition, through the marketplace. The promotional activities are still not optimal, is not able to generate demand.

Another drawback lies in the business actors themselves are weak entrepreneurial competence. The phenomenon that appears in the ceramic industry in West Java, businesses run slowly if not accompanied by the formation of government or other parties, while many artisans who accompanied the government and other parties look ahead. This indicates that the craftsman depends on the builder. The more intensive coaching, the possibility of moving forward. But, of course, a greater dependence is not good if continued prolonged. This will hamper the development, due to the rapid development takes initiative, creativity of the artisans themselves. This indicates that the entrepreneurial competence of ceramic artisans in West Java low.

This study will review it in terms of market strategy, marketing mix strategy and entrepreneurial competence attributed to the competitive advantage of marketing and its implications on marketing performance. It is based on the opinions Kotler and Keller (2016 p.178) states that one of the factors that 
determine the performance of a company that is the strategies that accompany the product (marketing mix strategies, market strategies). One powerful determinant with regard to small businesses are entrepreneurial competence (Sya'roni, 2012, p.6), which will affect the competitive advantage. Marketing performance will be difficult pursued when the ability of craftsmen (entrepreneurial competence) does not develop, because all aspects concerning the improvement of business performance ceramics, all sourced from ceramics businessman competence itself. Although the government and other parties helped, but not forever, and only in small portions, while business / big decisions remain on the shoulders of artisans. Nursya'bani et al, (2013, p.112) states that the sources of competitive advantage in marketing among others include product differentiation, service differentiation. The third variable (market strategy, marketing mix strategy and entrepreneurial competencies) affect the competitive advantage (Fitriany, 2013) and has implications for marketing performance (Ferdinand, 2015).

\section{Method}

This research is descriptive and verificative. The research was conducted in 2018 - 2019. The research in the region of West Java province, spread in several districts of Purwakarta district, the district of Cirebon, Majalengka regency, district, Cianjur and Bandung. Source of research data from two types of sources of primary data and secondary data, while the data collection method was performed using several techniques as well, namely: observation, interviews, surveys using questionnaires and literature study.

Primary data were obtained from the ceramic business owners in West Java and the respondent. Secondary data is data obtained from the results of previous studies, literature-related literature, data on artisans as well as other relevant documents. Secondary data consists of the profile data and the development of ceramic artisans in West Java. Data to be processed further, is converted first into an interval scale. Method of successive interval (MSI) can be used to change the ordinal data into interval scale. The population in this study are 404 artisans.
The data in this research is Structural Equation Modeling / SEM (Ghozali, 2011). Related to hypothesis testing, engineering sample size that is most appropriate to be used is the technique of power analysis. Sutiksno (2017: 97) stated that the sample size for SEM by using power analysis. The results of calculation of sample size with power test of 220. research instrument was a questionnaire which first tested the validity and reliability using the formula product moment correlation or Pearson's product moment coefficient of correlation. The reliability was calculated using Cronbach Alpha.Normality test is performed to determine whether the data follow a normal distribution or not. According Sugiyono (2018), to determine whether the data follow a normal distribution can be done by various methods, including the method Kolmogorof Smirnov and Shapiro Wilk method. The following variables and dimensions described in Figure 1:

Table 1

Variables and Dimensions

\begin{tabular}{ll}
\hline X1: Market Strategy & X2: Marketing \\
X11 = consumer & Mix Strategy \\
market segmentation & X21 = Product \\
X12 = Segmenting & X22= Price \\
industrial markets & X23 \\
X13= Determination & Distribution \\
of the target market & X24= Promotion \\
(Targeting) & \\
X14= Determination & \\
of market position & \\
(Positioning) & \\
\hline X3: Entrepreneurship & Y = Competitive \\
Competence & Advantage \\
X31 = Competence & Marketing \\
networking & Y1 = Product \\
X32 = technical & Differentiation \\
competence & Y2 \\
X33 = Competence & Differentiation of \\
marketing & Services \\
X34 = financial & Z = Marketing \\
competence & Performance \\
& Z1 = Proceeds \\
& from sale \\
& Z2 = Volume of \\
& sales \\
\hline & Z3= market share \\
\hline &
\end{tabular}

Hypothesis testing is done by using the $t$ test (comparing $\mathrm{t}$ arithmetic with $\mathrm{t}$-table) to see 
whether there is a variable influence on other variables, with a confidence level of $95 \%$ (margin of error of 5\%), while to determine how much influence derived from the analysis of SEM, and the models must be goodness of fit indeces. The hypothesis formulated in table 2 .

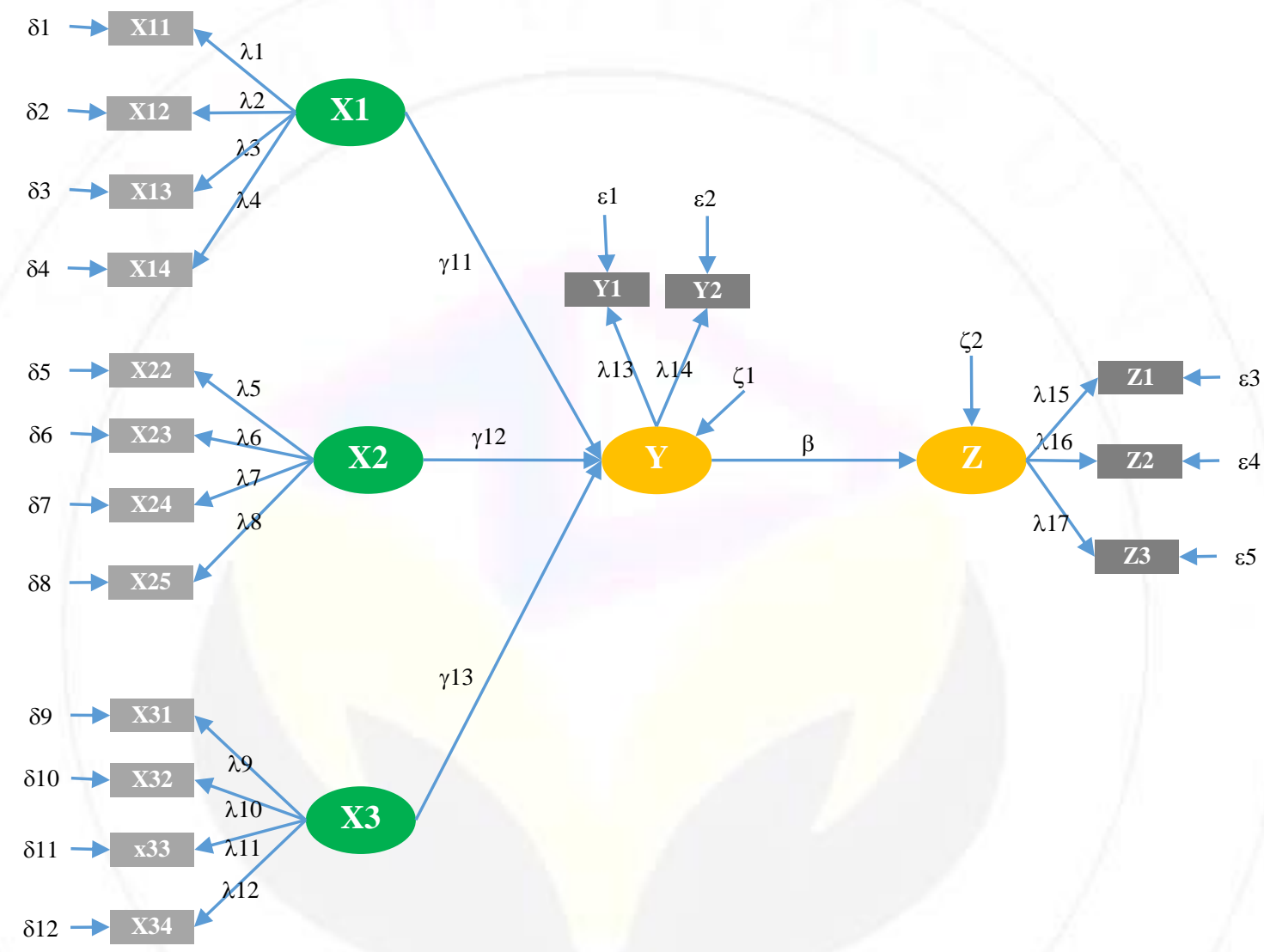

Picture 1

Model relationship marketing strategy, entrepreneurial competence, the competitive advantage of marketing and marketing performance

Table 2

Research hypothesis

Hypothesis 1: H0: $\mathrm{Y} 1=0 \quad$ Market strategy does H1: $\mathrm{y} 1 \neq 0$ not affect the competitive advantage of marketing

Market strategies affect the competitive advantage marketing

Hypothesis 2: $\mathrm{H} 0: \mathrm{y} 2=0$ H1: $\mathrm{y} 2 \neq 0$

Marketing mix does not affect the competitive advantage of marketing

Marketing mix effect on the competitive 


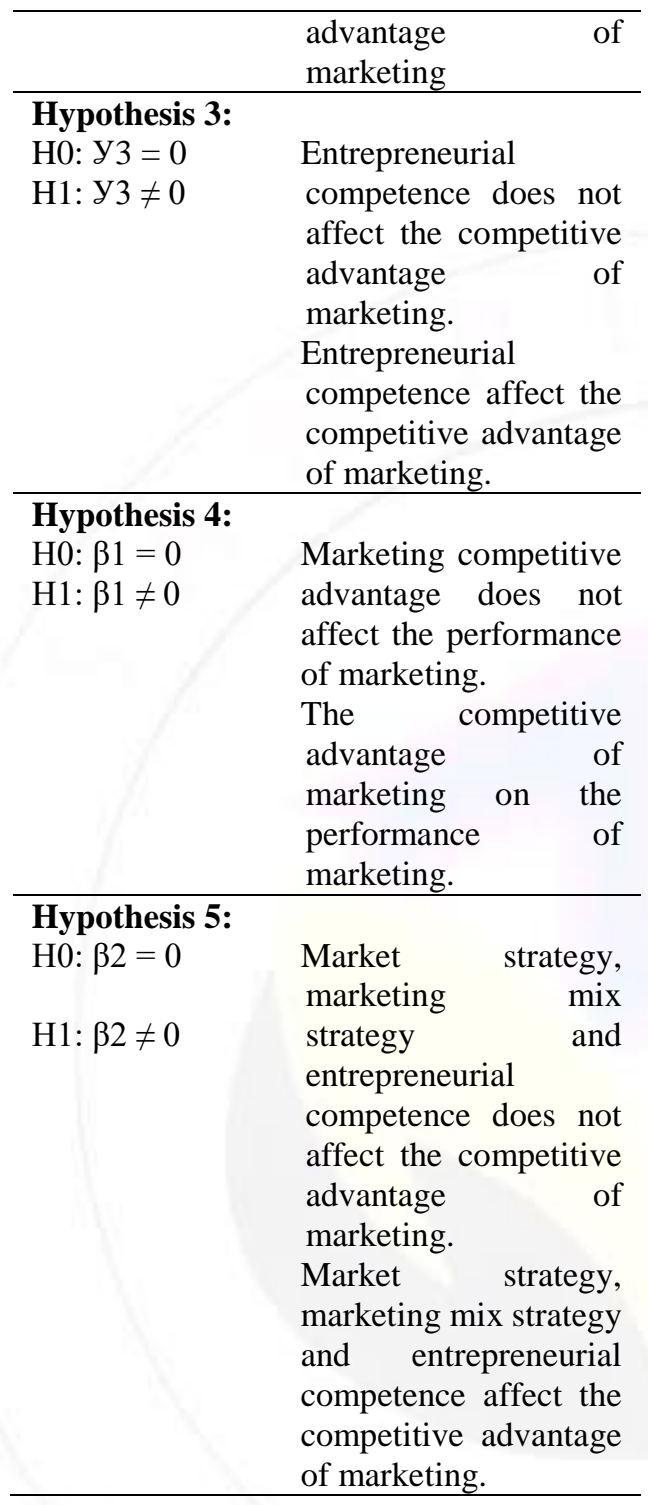

\section{Results and Discussion}

Before I present the results and discuss them, will be disclosed prior review of the literature relating to the variables studied. Here is an explanation of market strategy, marketing mix strategies, entrepreneurial competence, the competitive advantage of marketing, performance marketing, iconic products and ceramic products.

\section{A. Market strategy}

According to Baker (2014, p.5), says that "Marketing strategy is known as the resource-based approach, proponents of this view Consider the successful firm as a bundle of somewhat unique resources and capabilities. If the firm's core capabilities are scarce, durable, defensible or hard to imitate and can be closely aligned with the key success factors of the target markets ".

Kotler and Keller (2016, p.28) says market strategy is a strategy in which the company does not emit its marketing efforts but focuses on consumers who have the greatest opportunity to be served and satisfied.Market segmentation consists of an attempt to identify a group into a group have in common. Thus the market segmentation is viewed as creative, segmentation is the art to identify and exploit the opportunities emerging in the marketplace. Market segmentation has several advantages compared to mass market among other companies to create products and services that fit the target market. The company also will be easier to establish distribution channels and to establish marketing communications. Basic consumer market segments consist of geographic, demographic, psychographic and behavioral. $\mathrm{He}$ also explained that the terms good segment of them are large, scalable, and accessible. Bob Sabran (2016, p.248) adds that this segment of the market is not only limited to the consumer market segments, but also there is a market segment of industry, where the market is composed of the industrial market, with the following characteristics: demographics (industry, company size, location), variable operation, approach the purchase, factors situational, personal characteristics. Other segments are segments of the international market / abroad.

Next is to evaluate the different segments to decide which segments to target market (targetting). In evaluating different market segments the company should look at two factors: the overall market attractiveness and objectives and resources of the company (Kotler \& Keller, 2016, p.75). Companies should look at whether a potential segment has generally interesting characteristics such as size, growth, profitability, economies of scale, risk, competitive advantage, competitive situation. In this study indicators used dalah size, competitive advantages and the competitive situation.

Determination of the position (Positioning) is the act of designing an offer and image of the organization so that occupies a distinguished position (between 
competitors) in the minds of its target customers. The aim is to distinguish the determination of the position following the organization's perception of products and services from competitors (Lupiyoadi, 2014). Determination of the position of many forward the elements of communication and a communication strategy. Determination of the position can be made byattributes, benefits, competitors, the quality / price.

\section{B. Marketing Mix Strategy}

The marketing expert defines the marketing mix as expressed by Kevin (2015, p.487): "Marketing mix is the set of controllable marketing variables that the firm blends to produce the response", Ali (2016) states that: "In essence marketing mix are variables that the organization controls to influence its customers in order to Achieve its own objective".

Kotler and Keller (2016, p.63), classifies marketing tools into four groups known as the 4Ps of marketing: product, price, place, and promotion. Each of the $4 \mathrm{P}$ elements shown in Figure 2.

Kotler \& Armstrong (2016, p.248) defines the product as: "A product as anything that can be offered to a market for attention acquisition, use or consumption that Might satisfy a want or need Products include more than just tangible objects such as cars, computers or cell phones broadly defined" products "Also include service events persons, places, organisasi, ideas, or mixes of these".

Rahmayanti (2018, p.80) that the product quality or pricing strategies to influence the product strategy, where products with high quality provides opportunities for companies to set a high price with a high level of luxury to the product, and provide a high level of profitability to the company.

So the product is defined as anything that can be offered to the market to meet the desires and needs. Kotler and Keller (2016, p.163) states the product concept proposes that consumers prefer products that offer the most quality performance, or innovative features. Therefore, managers in the organization to focus on product quality and to improve the quality of these products all the time. Indicators in this study isproduct diversity, quality, design, traits / characteristics / uniqueness (local), warranty, guarantee.

Kotler and Keller (2016) says that a company must set a price for the first time when developing new products, when introducing products into new distribution channels regular or geographical area, and when entering the job offer on a new contract. Companies must decide where to position the product at quality and price has become an important factor influencing the choice of the buyer. Therefore, prices may affect consumers in deciding whether to buy the product or not, and how much that will be purchased based on those prices. Prices are often used as indicators of quality for consumers. Consumers will use these values to evaluate the price of the product. If the customer considers the price is higher than the value of the product, they will not buy the product.

Distribution channel serves to connect the manufacturer, or service provider, with customers or users. (Ting, et, all, 2013). The word 'channel' has its origins in the word for the channel, which for marketing can be defined as the route taken by the product because the product flow from production to the use of medium and late (Shank, et, all, 2014). Location is a very important factor as it relates to pricing, more / length of the distribution channel involved in delivering products from the manufacturer to the consumer, where each dealer took the margin, as a result price to the end consumer or higher can also impact on increasingly thin margins taken by the manufacturer. When the consumer perceived high price, although the products offered are nice, but the value of competitive advantage is reduced. If the high prices it charged to the producers, the producers do not get a decent margin, as a result of business continuity are facing bankruptcy because it is not interesting anymore. Factors that determine the competitive advantage that comes from the location that is $\mathrm{p}$ consequently the price to the end consumer or higher can also impact on increasingly thin margins taken by the manufacturer. When the consumer perceived high price, although the products offered are nice, but the value of competitive advantage is reduced. If the high prices it charged to the producers, the producers do not get a decent margin, as a result of business continuity are 
facing bankruptcy because it is not interesting anymore. Factors that determine the competitive advantage that comes from the location that is $\mathrm{p}$ consequently the price to the end consumer or higher can also impact on increasingly thin margins taken by the manufacturer. When the consumer perceived high price, although the products offered are nice, but the value of competitive advantage is reduced. If the high prices it charged to the producers, the producers do not get a decent margin, as a result of business continuity are facing bankruptcy because it is not interesting anymore. Factors that determine the competitive advantage that comes from the location that is $\mathrm{p}$ Business continuity consequently threatened with bankruptcy because it is not interesting anymore. Factors that determine the competitive advantage that comes from the location that is pgathering is distribution, types of outlets / retail, range, number of channels, availability of facilities, distribution speed. In this study, the indicator is the length distribution, range, number of channels, speed distribution, the number of outlets.

In essence, the campaign is a form of marketing communications. Marketing communications is a marketing activity that seeks to disseminate information, influence / persuade, and / or warn the target market for the company and its products to be willing to accept, purchase, and loyal to the products offered by the company concerned. Communication carries the information of interest to customers, designed to persuade customers to buy a product, at present or in the future. According to Kotler and Armstrong (2016, P.76), "Promotion means activities that communicate the benefits of the product and persuade targeted customers to buy it. Factors to be considered in the promotion (Lupiyoadi, 2014, p.123), namely 1) Identification of the first audience tergetnya: this associated with market segmentation. 2) Determine the purpose of the promotion: whether to inform, influence, or remind. 3) Develop the message delivered: this relates to the content of the message (what to say), the structure of the message (how to deliver the message logically), the style of the message, the source of the message. Indicators of promotion in this study is the media and the media intensivity.

\section{Entrepreneurship Competence}

Entrepreneurial competence is the knowledge, attitudes and skills that are connected to each other, which required employers to be trained and developed to be able to produce the best performance in managing their business (Muzakar, 2011, p.161).

Entrepreneurial competence is divided into 4, among others (Sya'roni, et, all, 2012, p.7): 1) the competence of human relations (human relations competencies), entrepreneurial competence related to the ability to maintain, build, develop good relationships with people , as well as the parties concerned with the company's activities, such as with coworkers, employees, distributors of goods, materials suppliers, investors, creditors, communities.

2) technical competence, entrepreneurial competence associated with the technique, how, materials and labor that produces furious and services produced by the company. 3) Competence marketing, entrepreneurial competence related to the ability of entrepreneurs in the field of product marketing. This capability includes expertise to do market research, choose a marketing strategy, combining profitable marketing mix. 4) financial competence, entrepreneurial competence in managing finances, especially looking for the cheapest funding source, use and invest the funds were profitable, making the right budget and split the profit on the business profits to satisfy all interested parties.

\section{Competitive Advantage Marketing}

Competitive advantage is defined as a company occupies an invincible position in which the company's competitors can not replicate strategies with ease and companies can obtain long-term benefits of the strategy with success (Porter, 2011) and said that the source of competitive advantage can be divided into two types: advantages cost and differentiation. Excellence is how much a company's product prices lower than their competitors in the market. Differentiation is a unique product that is granted a superior company or benefits given to customers than competitors' products. In addition a unique and superior benefits to meet the needs of customers. Product differentiation is one of the main activities were very important in the 
face of a competitive business competition, Bob Sabran (2016, p.5) concluded that the product is one of the main factors in marketing that became the focal point of attention, followed by other variables.

According to Baker (2014), to achieve good performance, the company should produce a unique product, in contrast, can not be imitated / can not be replaced (Wang, et, all, 2014). Indicators of competitive advantage consists of quality, resilient, product novelty and uniqueness of the product (Lydia, 2015). Haapanen, et al (2018) stated that the competitive advantage of the product leads to the creation of superior value for customers relative to what is offered by competitors. Gina, Suendro. (2010) states that the competitive advantage of the product is the perceived level of product design, attributes, and quality relative to the competition.Competitive advantage is the company's ability to formulate strategies for achieving profit opportunities through the maximization of revenue from the investments made. Nursya'bani, et, all (2013, p.112) said that the sources of competitive advantage in marketing is Customer service before and after the sale. The adjustment is as follows:ease of booking, serve speed, ease of payment.

\section{E. Performance Marketing}

Functionally, the company's performance will be reflected in the performance of human resources, performance production, marketing performance, and financial performance (Ferdinand, 2015). Marketing performance seemed on the high market share and high profitability of marketing. According to research by Shu-Hao Chang et al (2012) to measure the dimensions of business performance with sales growth, employment growth, market share, gross profit, net profit margin, innovation and service, cost control and customer satisfaction. Performance marketing is a part of the organization's performance. Performance marketing is a measure of achievement gained from the activities of the overall marketing process of a company or organization. In this study, an indicator of performance marketing is increasing sales, increasing sales volume, breadth of coverage area market, an increasing number of visitors to the outlets / shops.

\section{F. Iconic Products}

Sebaga iconic products defined product that has aspects that contribute to consumer self-expression and personal identity. Brands that have a consumer value mainly comes from the value of identity, is said to have a brand identity. Some brands have a strong identity that yagn them more or less become a cultural icon that makes them so-called "brand icons", for example is Apple, Nike and Harley Davidson. Many iconic brand rituals involves behaviors such as purchase or consume the product. Expressive product value, carrying symbolic attributes. This product follows the social and psychological interpretation of purchasers or users of the product. The icon is a sign that contain similarities such that the mark is easily recognizable by the wearer. Iconic models are easily observed, was formed and described,

\section{G. Ceramic Products}

The term comes from the Greek ceramics (Keramos) which means the pot or pot made of baked clay ". Ceramic is the result of a craft works made by human hands using human hands using clay as the main material is then processed and burnt. Ceramic craft type are generally classified into two parts, namely the traditional ceramics and modern ceramics. Model traditional ceramics can not be changed either in terms of shapes, patterns and functions of pottery because it contains the meaning of religious philosophy that should not be changed arbitrarily, while the modern ceramics experienced growth in terms of both forms. Motifs and functions in order to adapt to the times. Generally craft ceramics have characteristics that are diverse in terms of function, type, shapes and motifs. The function of the ceramic craft than as functional objects as well as decorative objects. Ceramic type is divided into three parts, namely ceramic types Earthenware, stoneware and porcelain. As for the shape of the ceramic craft there are shaped twodimensional, three-dimensional, shape figurative, non-figurative forms and abstract (Bieber et, all, 2013, p3). 


\section{H. Result (Research Findings)}

The first stage is a structured model testing is described in Table 3:

Table 3

Regression coefficient / SEM Model Line

\begin{tabular}{cccc}
$\begin{array}{c}\text { Latent } \\
\text { Variables } \\
\text { Endogenous }\end{array}$ & to & $\begin{array}{c}\text { variables } \\
\text { latent } \\
\text { exogenous }\end{array}$ & $\begin{array}{c}\text { estimate } \\
\text { Parameter }\end{array}$ \\
\hline $\mathrm{Y}$ & $\leftarrow$ & $\mathrm{X} 1$ & 0.183 \\
\hline $\mathrm{Y}$ & $\leftarrow$ & $\mathrm{X} 2$ & 0.345 \\
\hline $\mathrm{Y}$ & $\leftarrow$ & $\mathrm{X} 3$ & 0.469 \\
\hline $\mathrm{Z}$ & $\leftarrow$ & $\mathrm{X} 1$ & 0.198 \\
\hline $\mathrm{Z}$ & $\leftarrow$ & $\mathrm{X} 2$ & 0.292 \\
\hline $\mathrm{Z}$ & $\leftarrow$ & $\mathrm{X} 3$ & 0,287 \\
\hline $\mathrm{Z}$ & $\leftarrow$ & $\mathrm{Y}$ & 0,305 \\
\hline
\end{tabular}

Source: Data Analysis, 2019

Based on Table 3 is known that the Market Strategy (X1), Marketing Mix Strategy (X2), and Entrepreneurship Competence (X3) significantly affects Competitive Advantage Marketing $(\mathrm{Y})$ is indicated by the value of $\mathrm{t}>1.96$. Likewise Market Strategy (X1), Marketing Mix Strategy (X2), and Entrepreneurship Competence (X3) have a significant influence on Marketing Performance (Z), because it has the absolute value of the test statistic is greater than 1.96. Competitive Advantage Marketing (Y) also have a significant influence on Marketing Performance $(\mathrm{Z})$, because it has the absolute value of the test statistic is greater than 1.96 .

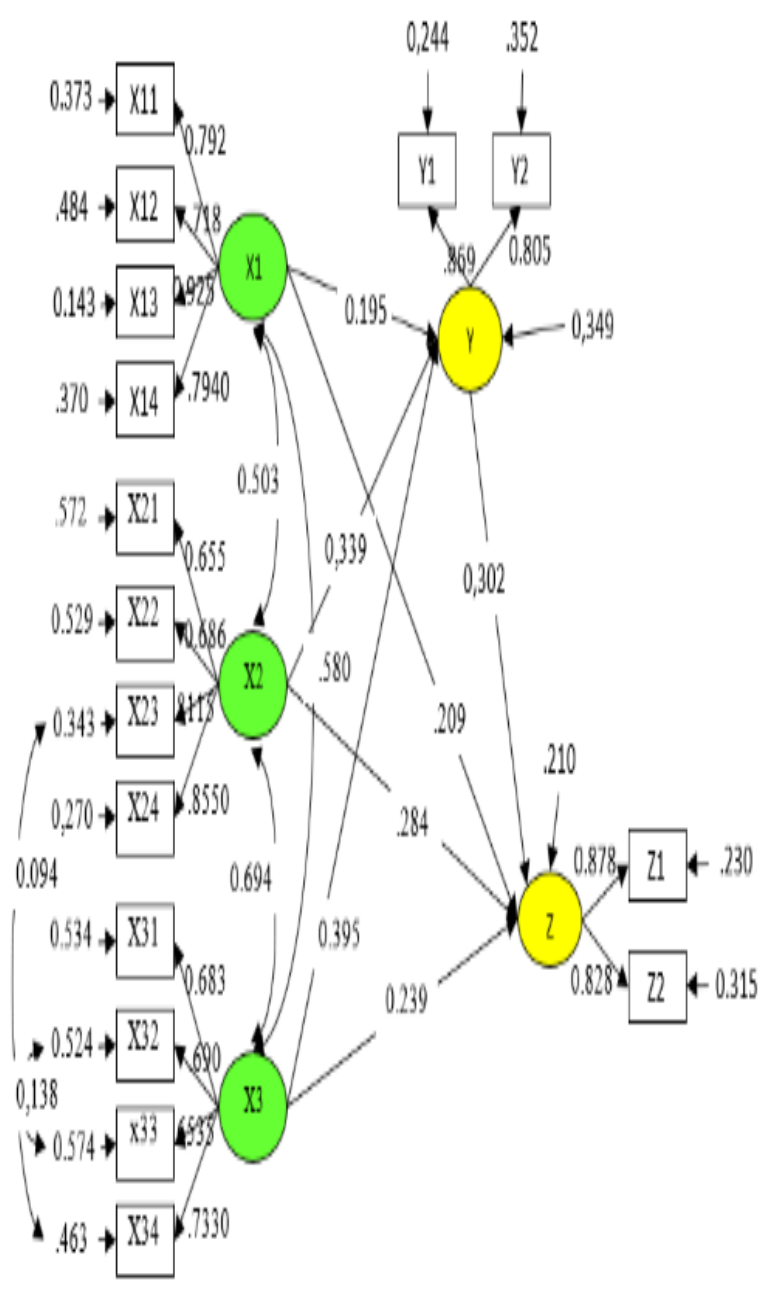

Figure 2 
Market Strategy, Marketing Mix Strategy and Entrepreneurship Competence to Competitive Advantage Marketing partially or simultaneously depicted in Table 4:

Table 4

Effect of Market Strategy, Marketing Mix Strategy and Entrepreneurship Competence to Competitive Advantage Marketing

\begin{tabular}{|c|c|c|c|c|c|c|c|}
\hline \multirow{2}{*}{ variables } & \multirow{2}{*}{$\begin{array}{c}\text { path } \\
\text { coefficient }\end{array}$} & \multirow{2}{*}{$\begin{array}{l}\text { Influence } \\
\text { Directly }\end{array}$} & \multicolumn{3}{|c|}{ Indirect Influence (PTL) } & \multirow{2}{*}{$\begin{array}{l}\text { Total } \\
\text { PTL }\end{array}$} & \multirow{2}{*}{$\begin{array}{l}\text { Sub. } \\
\text { Total }\end{array}$} \\
\hline & & & X1 & $\mathrm{X} 2$ & $\mathbf{X 3}$ & & \\
\hline $\mathrm{X1}$ & 0.195 & 0.038 & & 0,033 & 0.045 & 0.078 & .116 \\
\hline $\mathrm{X} 2$ & 0,339 & 0,115 & 0,033 & & 0.093 & 0.126 & 0.241 \\
\hline \multirow[t]{2}{*}{$\mathbf{X 3}$} & 0.395 & 0,156 & 0.045 & 0.093 & & 0,138 & .294 \\
\hline & & & Total Eff & & & & 0.651 \\
\hline
\end{tabular}

Source: Data Processing, 2019

Based on the above table, the amount of direct influence on competitive advantage strategy marketing market is $3.8 \%$, the magnitude of the direct influence of marketing mix strategy on competitive advantage of marketing is $11.5 \%$, the magnitude of the direct influence of entrepreneurial competencies to competitive advantage of marketing is $15.6 \%$. Marketing competitive advantage is influenced by market strategy, marketing mix strategy and entrepreneurial competence by $65.1 \%$ and the remaining $34.9 \%$ influenced by other factors (ceteris paribus).

Table 5

Effect of Market Strategy, Marketing Mix Strategy and Entrepreneurship Competence to Competitive Advantage Marketing and Its Impact on Marketing Performance

\begin{tabular}{|c|c|c|c|c|c|c|c|c|}
\hline \multirow{2}{*}{ variables } & \multirow{2}{*}{$\begin{array}{c}\text { path } \\
\text { coefficient }\end{array}$} & \multirow{2}{*}{$\begin{array}{c}\text { Influence } \\
\text { Directly }\end{array}$} & \multicolumn{4}{|c|}{ Indirect Influence (PTL) } & \multirow{2}{*}{$\begin{array}{l}\text { Total } \\
\text { PTL }\end{array}$} & \multirow{2}{*}{$\begin{array}{l}\text { Sub. } \\
\text { Total }\end{array}$} \\
\hline & & & $\mathrm{X} 1$ & $\mathrm{X} 2$ & $\mathrm{X} 3$ & $\mathrm{Y}$ & & \\
\hline X1 & .209 & 0,044 & & 0,030 & 0,029 & 0.038 & 0.097 & 0.141 \\
\hline $\mathrm{X} 2$ & .284 & 0.081 & 0,030 & & 0,047 & 0.061 & 0,138 & .219 \\
\hline X3 & 0.239 & 0.057 & 0,029 & 0,047 & & 0,054 & .130 & 0.187 \\
\hline $\mathbf{Y}$ & 0,302 & 0.091 & 0.038 & 0.061 & 0,054 & & 0.152 & 0,243 \\
\hline
\end{tabular}

Source: Data Processing, 2019

Based on the above table, it is known that the magnitude of the direct effect of the competitive advantage of marketing to marketing performance by $9.1 \%$,

Hypothesis testing

1. Hypothesis Testing Market Strategy Against Competitive Advantage Marketing
Table 6

Test Effect of Market Strategy (X1) to the Competitive Advantage Marketing (Y)

\begin{tabular}{ccccccc}
\hline End & & Lat & & & & \\
ogen & ent & Reg & stan & Sta & \\
ous & & exo & ress & dardi & nda & \\
Late & $\mathrm{t}$ & gen & ion & zed & rd & t \\
nt & o & ous & coef & esti & err & \\
Vari & vari & . & mate & or & \\
able & able & & & & \\
\hline
\end{tabular}

\footnotetext{
$\mathrm{H} 0,1: \gamma_{11}=0 \quad: \quad$ There is no influence market strategy on competitive advantage of

$\mathrm{H} 1,1: \gamma_{11} \neq 0$ marketing $\leftarrow \quad 8$ There is the influence of market strategy (tol 8 ompetitive0 advaroage marketing
$\begin{array}{cccc}\text { Y } & \mathrm{X} 1 & 3 & 71 * \\ * & *\end{array}$ Source: Data Analysis, 2019


Based on the above table, the value of $\mathrm{t}$ count equal to 2,589, while the t-table value (critical value $\mathrm{z}$-standard normal distribution), using test two parties, the confidence level of $95 \%$, obtained by 1.96 . T value $=2.589>1.96$, so that the null hypothesis is rejected. This means that influences of market strategy (segmentasi consumer market, industrial market segmentation, target market determination / targetting, and the establishment of market position/ Positioning) on competitive advantage of marketing.

2. Hypothesis Testing Strategy Against Competitive Advantage Marketing Mix Marketing $\mathrm{H} 0,2: \gamma_{12}=0$

$\mathrm{H} 1,2: \gamma_{12} \neq 0$

\section{Entrepreneurship Competence Hypothesis Testing Against Competitive Advantage Marketing $\mathrm{H} 0,3: \gamma_{13}=0$ : There is no influence of entrepreneurial competencies to competitive advantage marketing H1,3: $\gamma_{13} \neq 0$ : There is the influence of entrepreneurial competencies to competitive advantage marketing}

Table 7

Test Effect of Marketing Mix Strategy (X2)

to the Competitive Advantage Marketing

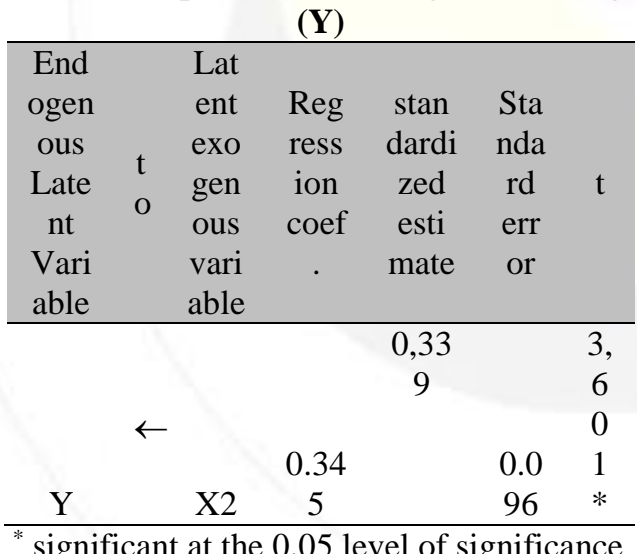

Source: Data Analysis, 2019

Based on the above table, the value of t count equal to 3,601, while the t-table value (critical value $\mathrm{z}$-standard normal distribution), using test two parties, the confidence level of $95 \%$, obtained by 1.96 . T value $=3.601>1.96$, so that the null hypothesis is rejected. This means that influences of the marketing mix (product, price, distribution, promotion) on competitive advantage of marketing.
Table 8

$$
\text { Test (X3) }
$$

to the Competitive Advantage Marketing

\begin{tabular}{|c|c|c|c|c|c|c|}
\hline \multirow[b]{2}{*}{$\begin{array}{c}\text { End } \\
\text { ogen } \\
\text { ous } \\
\text { Late } \\
\text { nt } \\
\text { Vari } \\
\text { able }\end{array}$} & \multirow[b]{2}{*}{$\begin{array}{l}\mathrm{t} \\
\mathrm{o}\end{array}$} & \multicolumn{4}{|c|}{$(\mathbf{Y})$} & \\
\hline & & $\begin{array}{c}\text { Lat } \\
\text { ent } \\
\text { exo } \\
\text { gen } \\
\text { ous } \\
\text { vari } \\
\text { able }\end{array}$ & $\begin{array}{c}\text { Reg } \\
\text { ress } \\
\text { ion } \\
\text { coef } \\
.\end{array}$ & $\begin{array}{l}\text { stan } \\
\text { dardi } \\
\text { zed } \\
\text { esti } \\
\text { mate }\end{array}$ & $\begin{array}{c}\text { Sta } \\
\text { nda } \\
\text { rd } \\
\text { err } \\
\text { or }\end{array}$ & $\mathrm{t}$ \\
\hline Y & $\leftarrow$ & X3 & $\begin{array}{c}0.46 \\
9\end{array}$ & $\begin{array}{c}0.39 \\
5\end{array}$ & $\begin{array}{l}0.1 \\
32\end{array}$ & $\begin{array}{l}3 . \\
5 \\
5 \\
3 \\
*\end{array}$ \\
\hline
\end{tabular}

* significant at the 0.05 level of significance Source: Data Analysis, 2019

Based on the above table, the value of t count equal to 3.553 , while the t-table value (critical value $\mathrm{z}$-standard normal distribution), using test two parties, the confidence level of $95 \%$, obtained by 1.96 . T value $=3.553>1.96$, so that the null hypothesis is rejected. This means that influences of entrepreneurial competence (competence networking, technical competence, marketing competence, financial competence) on competitive advantage of marketing. 
4. Hypothesis testing Market Strategy, Marketing Mix Strategy and Entrepreneurship Competence AgainstCompetitive Marketing Simultaneously

Hypothesis research to determine the effect of Market Strategy, Marketing Mix Strategy, dan Entrepreneurship competence to simultaneously Competitive Advantage Marketing is as follows:

$\mathrm{H} 0,4: \gamma_{11}=\gamma_{12}=\gamma_{13}=0$

$\mathrm{H} 1,4: \gamma_{11} \neq \gamma_{12} \neq \gamma_{13} \neq 0$

\begin{tabular}{ccccccc}
\hline End & & Late & & & & \\
ogen & & nt & Reg & stan & Sta & \\
ous & & end & ress & dard & nd & \\
Late & t & oge & ion & ized & ard & t \\
nt & o & nous & coef & esti & err & \\
Vari & & vari &. & mate & or & \\
able & able & & & & \\
\hline
\end{tabular}

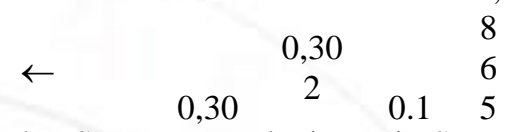

There is no influencZ Market Strategy, 5 Marketing Mơx Strategy

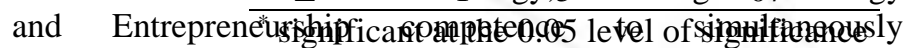
Competitive Advastomedediaketingalysis, 2019

: There is the influence of Market Strategy, Marketing Mix

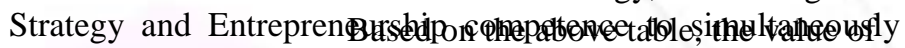
Competitive Advaetaget Marketing, 865 , while the t-table value

Because of $\mathrm{F}=134.116>\mathrm{F}$ table $=$ 2.646 then $\mathrm{H} 0$ is rejected, meaning that there is the influence of Market Strategy, Marketing Mix Strategy and Entrepreneurship Competence to Competitive Advantage Marketing simultaneously. The magnitude of the effect of Market Strategy, Marketing Mix Strategy and Entrepreneurship Competence to Competitive Advantage Marketing for $65.1 \%$, while the remaining $34.9 \%$ influenced by other factors.

5. Hypothesis Testing Against Competitive Advantage Marketing Marketing Performance follows:

The hypothesis to be tested are as

$$
\mathrm{H} 0,8: \beta=0
$$

$\mathrm{H} 1,8: \beta \neq 0$

The following table is a test of the influence of Competitive Advantage Marketing ( $\mathrm{Y}$ ) consisting of Excellence dimensional product differentiation, service differentiation and excellence on the Performance Marketing consists of the dimensions of sales volume and market share.

Table 9

Test Effect of Competitive Advantage Marketing (Y)

the Performance Marketing (Z) (critical value $\mathrm{z}$-standard normal distribution), using test two parties, the confidence level of $95 \%$, obtained by 1.96 . T value $=2.865>1.96$, so that the null hypothesis is rejected. This means that influences of the competitive advantage of marketing (product differentiation excellence, excellence of service differentiation) on competitive advantage of marketing.

\section{Discussion}

1. Effect of Market Strategy Against Competitive Advantage Marketing

According to Kotler and Keller (2016), concerning market segmentation strategy which consists of market segmentation of consumer and industrial market segmentation, target market

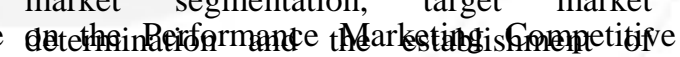

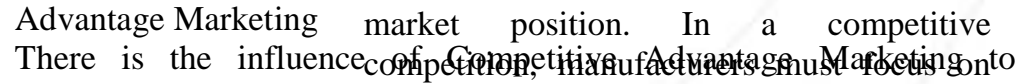
Marketing Performance serving one or several segments of consumers, does not serve all consumers. Focus attention on the segment further facilitate the marketing strategy and will be more effective. Segmentation including the determination of the target market influence purchasing decisions by Annetta et, all (2016), it indicates that through segmentation can facilitate manufacturers in determining the right strategy so that the products and services of superior worth. Anna et, all (2014) proved that the strategy of positioning is helping small businesses in placing the product in the hearts of consumers so as to strengthen its position in the competitive landscape. Henrik, et, all (2015) says that 
positioning is important for the product including the town. Munandar (2011) support the development of a hospital through market strategy (segmenting, targeting, positioning).

West Java ceramics SMEs focusing mostly serve certain segments namely foreign segment, focusing attention on foreign markets makes it easy to create a marketing strategy and generate superior value so that the market can be maintained and the number is growing. Implementation of the marketing strategy can not be fully done by yourself but aided by the government and other parties through training programs in product design, innovation, facilitate / provide assistance in the form of grants machine, providing exhibition space to the promotion of online or other forms. Sustainable strategies and programs continue until the proper positioning on the right segment.

\section{The influence of marketing mix strategies to competitive advantage marketing}

Ali, Muhammad, et, all (2016) proved that the marketing mix influence purchasing decisions. Kevin, Wongleedee (2015) support the development of traditional markets through effective marketing mix strategy. Nugroho (2013) says there is significant influence marketing mix strategy (people,physical evidence, product, promotion, price and place) to the level of visits. Owomoyela (2013) proved that influence loyalty marketing mix. Rahmayanti (2018) said the marketing mix affects the value of the customer.

The owners of SMEs ceramic strives to improve its ability particularly in developing products, seeks efficiency costs, increase efforts to expand the distribution network and seeks cooperation with several parties to promote ceramics. A very strong competitor from Vietnam and China, which continues to shift the position of Indonesia in the international market ceramic, facing the artisans through the efforts responsive to environmental changes. Business owners who diligently follow training programs and is always involved in the association, more advanced even able to get orders exceed production capacity.

\section{Effect of entrepreneurial competencies to competitive advantage marketing}

Entrepreneurial competence is smaller than the effect of other variables, but remains influential. This indicates that internal factors business owners helped determine the success of ceramic tiles. Pratomo (2015) have proved that the entrepreneurial competence affect competitive advantage in order to improve marketing performance. Utomo (2015) support the development of entrepreneurship interest which is driven entrepreneurial competence within each of businessmen. Sya'roni (2012) said it was important the development of entrepreneurial competence through the development of creativity and innovation. Entrepreneurs entrepreneurial competence in ceramics in western Java enhanced through the stages of the method. The training was organized by the government so designed, to be able to create a change in creative business owners. There is a real product manufacturing training, some training that are fishing creativity. Other training especially regarding product support is still lacking, while this more training is pushing the capability of generating a nice ceramic products. As a result, there are some businesses were able to increase the entrepreneurial competence.

\section{Competitive advantage the influence of marketing on the performance of marketing \\ Haapanen (2018) said that the} importance of the company has a competitive advantage in supporting the performance of international companies. The statement was reinforced by Fitriany (2013) which says that the competitive advantage of the product is important in supporting the performance of SMEs. Ferdinand, et, all (2015) mentions a good marketing performance to be supported by efforts towards creating an attraction of product excellence. SME owners West Java ceramic courageous and able to innovate its products and services will have a competitive advantage. The advantages of product differentiation and services in the form of product variety, unique, distinctive, and not easily replaced by competitors, it will be difficult to imitate by competitors that will excel in the market.

Competitive competition must be balanced with ability. Ceramic business owners must focus on developing especially entrepreneurial competencies, because the 
results of the analysis show that these variables are the most important. Entrepreneurial competence is an internal factor, and determine the success of other variables is the ability to determine the right segment of market, to produce the quality goods, the right price, the effective chanel distributions, the effective promotion, so that it can produce high excellence and improve its welfare. The government is only as a facilitator, and only for a while, the determinant of success is yourself. The government and other institutions are limited to helping. On one side, business owners complained about the lack of equitable government programs, not all are involved as participants, but the government has denied it, the government considers business owners lazy to participate in various training. Entrepreneurs whose locations are close to UPTD building, their business are more advanced and exportable.

\section{Conclusion}

Based on the analysis and discussion can be concluded that the market strategy, marketing mix strategy and entrepreneurial competence affect the competitive advantage of marketing and marketing performance impact on SMEs iconic products ceramics in western Java. The direct effect of the independent variable intervening variable, the most chronologically is the competence of entrepreneurship, marketing mix strategy and market strategy, marketing to competitive advantage, while the amount of direct influence on the performance of competitive advantage marketing smaller than the marketing of three of the independent variables mentioned.

Based on data analysis and discussion, the authors recommend to increase the competitive advantage of marketing should business owners should further improve the competence of entrepreneurship, improving the ability of relating to the marketing mix strategy and capabilities associated with market strategies. These competencies can be improved through a variety of programs gradual, systematic and comprehensive, and therefore the government should be more serious about coaching, both the motivation and technical nature.

On the other hand, the business owner must very diligently follow the government program because only through these activities, capacity building relating to five variables studied can be achieved. Future research should be directed at deepening any more specific aspects of a more focused or compare with other regions that produce the same product using different analytical methods, or the same variables but different objects.

\section{Acknowledgement}

The research was carried out in support of the University of Pasundan Bandung and Bandung Islamic University.

\section{References}

Ali, Muhammad. Muhammad Ilyas., Chaudhary Abdul Rehman. (2016). Impact of consumer centric marketing mix elements on consumer buying behavior: an empirical investigation in the context of the FMCG industry on Pakistan. Quwait chapter of Arabian Journal of Business and management review, 5 (5).

Ana Maria Garcia, Perez, Vanessa, Yanes, Estevez., Juan Ramon, Oreja, Rodriguez. (2014). Strategic positioning and strategic types of small firms. Journal of Small Business and Enterprise Development, 21 (3), 431449.

Annetta, Gunawan., Raymond, Glean, Brian, Garda, Muchardie. (2016). Analysis of Millennial Moms Segmentation and Perceptual Mapping of Infant Formula Milk Market in Jakarta. Inktomi Business Review, 7 (3), 255-260.

Baker, Michael J. (2014). Marketing strategy and management. New York. Palgrave MacMillan Education.

Blanchard, Pierre., Carl Gaigne., Claude Mathiew. (2012). Trade costs and the international strategy of the firm: The role of endogenous product differentiation. Regional Science and Urban Economics, 42, 1023-1036.

Ferdinand, Augusty, Tae., Fitriany, Lili, Karmela. (2015). Acculturative iconic product attractiveness and marketing performance. Journal of Global Strategic Management, 9 (2), 15-23.

FITRIANI, Lili, Karmela. (2013). Effect of entrepreneurial orientation and market orientation towards product innovation 
and its impact on the competitive advantage of the product (research on SMEs Batik Cirebon). National Conference on Management Research VII Palembang, 2086-0390.

Gina, Suendro. (2010). Analysis of the influence of product innovation through marketing performance to achieve sustainable competitive advantage (Case studies on small and medium industries Batik Pekalongan). Diponegoro University Graduate Program.

Ghozali, Imam. (2011). Structural Equation Modeling: Concepts and Applications with AMOS 22.0, Update Bayesian SEM. Semarang: Diponegoro University Publishers Agency.

Haapanen, Lauri., Pia, Hurmelinna, Laukkanen., Jan, Hermes. (2018). Firm Functions and the nature of competitive advantage in internationalizing SMEs. International Journal of Innovation Management, 22 (3).

Henrik, Gert, Larsen. (2015). A Hypothesis of the dimensional organization of the city constructs a starting point for city brand positioning. Journal of Destination Marketing and Management 4, 13-23.

Kevin, Wongleedee. (2015). Marketing Mix and purchasing behavior for community products at traditional markets. Procedia: Social science end behavior.

Kotler, Philip and Armstrong, G. (2016). Principles of Marketing. New Jersey: Prentice Hall.

Kotler, Philip., \& Keller, Kevin Lane. (2016). A Framework for Marketing Management. London: Pearson Education Limited.

Lydia, Apriliani., Augusty, Tae, Ferdinand. (2015). Factors that influence the competitive advantage in an effort to increase market share. Diponegoro Journal of Management, 4 (3), 23373792.

Lupiyoadi, Creep. (2014) Marketing Services. Jakarta. Salemba Four.

Munaf, Triawan. (2017). Survey Results Statistical Data and Creative Economy: Creative Economy Cooperation Agency and the Central Bureau of Statistics. BPS.
Munandar, Dada. (2011). Analysis of the determination of the segment, targeting and positioning market homecare hospital Al-Islam Bandung. Scientific magazine UNIKOM, Bandung.

Musthopa, Budiman, Mahmud. (2017). Transformation of Small and Medium Enterprises Based Art Creativity Tradition: A Case Study of Saung Angklung Udjo in Bandung, West Java. Sosiohumanika, 10 (1), 57-70.

Muzakar, Isa. (2011). Competence Analysis of Entrepreneurship, Entrepreneurship Orientation and Performance furniture industry. Lppmums, 15 (2).

Nugroho, R., Japarianto, E. (2013). Influence people, physical evidence, product, promotion, price and place of the traffic in a cafe coffee cozies Surabaya. Petra Marketing Management Journal, 1 (2), 1-9.

Owomoyela, Ola., Oyeniyi. (2013). Investigating the impact of marketing mix elements on consumer loyalty: An empirical study on Nigerian Breweries Plc. Interdiciplinary Journal of Contemporary Research in Business.

Porter, ME (2011). The competitive advantage of nations: creating and sustaining superior performance (Vol. 2). Simon and Schuster.

Pratomo, MRT., Widiyanto, I. (2015). Analysis of the influence of entrepreneurial competence and the ability to sense market on competitive advantage to improve performance marketing (SME case study in the city of Semarang. Doctoral dissertation, Faculty of Economics and Business.

Rahmayanti, Rima. (2018). Target market and marketing mix in creating customer value as well as its implications on customer loyalty (a study of customer Tea Bags Walini in Bandung Metropolitan). Pasundan University, Institutional repositoris and scientific journals.

Sabran, Bob. (2016). Marketing Management. Jakarta. Erland.

Shank, MD, Lyberger, MR (2014). Promotion mix elements. In Sports Marketing, 407-463.

Shu-Hao Chang., Chia-Ho Chen, Yu Ching Ho. (2012). A Study of Marketing Performance Evaluation System for 
Notebook Distribution. International Journal of Business and Management, 7 (13), 1833-3850.

Sugiyono. (2018). Management Research Methods. Yogyakarta. Alfabeta.

Sya'roni., Deden, Abdul Wahab., Sudirham, J. J, (2012). Creativity and Innovation Competence Determinants Small business communities. Journal of Technology Management, 11 (01).

Ting, Low, Sheau., Abdul Hakim, Mohammed., Choong, Weng, Wai. (2013). What is the optimum mix of social marketing to market energy conservation behavior: An empirical study. Journal of environmental management, 13 (1), 196-205.

UPTD Research. (2010). Decorative Ceramic Techniques Guide. Plered. UPTD Research.

Utomo, H. (2015). Growing interest in social entrepreneurship. Among Makarti Scientific Journal, 7 (14).

Wang Chao, Hung. (2014). How relational capital mediates the effect of corporate reputation on competitive advantage: Evidence from Taiwan's high-tech industry. Technological Forecasting \& Social Change, 82 (2014), 167-176.

Regulation of the Minister of Industry of the Republic of Indonesia Number: 135 / M-IND / PER / 10/2009 concerning a guide map (road map) industry cluster development pottery and decorative ceramics.

Indonesian Banking Development Institute and Bank Indonesia, 2015, the Business Profile for Micro, Small and Medium Enterprises (SMEs).

Regulatory region of West Java Province No. 10 of 2010 on SMEs.

Indonesian Presidential Regulation No. 6 of 2015 concerning improvement of the creative economy through BEKRAF (Creative Economy Agency).

Presidential Decree No. 752015 about the creative economy.

SK Ministry of Industry 01 / M-Ind / PER / $1 / 2016$ on the application of SNI.

Indonesian Government Regulation No. 17 of 2013 on government support for innovative and creative businesses.

UPTD (Regional Technical Implementation Unit) Research \& Development, Ministry of Industry and Trade.

\section{Biography}

The author is a graduate student of Pasundan University Bandung, Management Science Doctoral program and worked as a lecturer in management studies program, Faculty of Economics and Business Universitas Islam Bandung. 